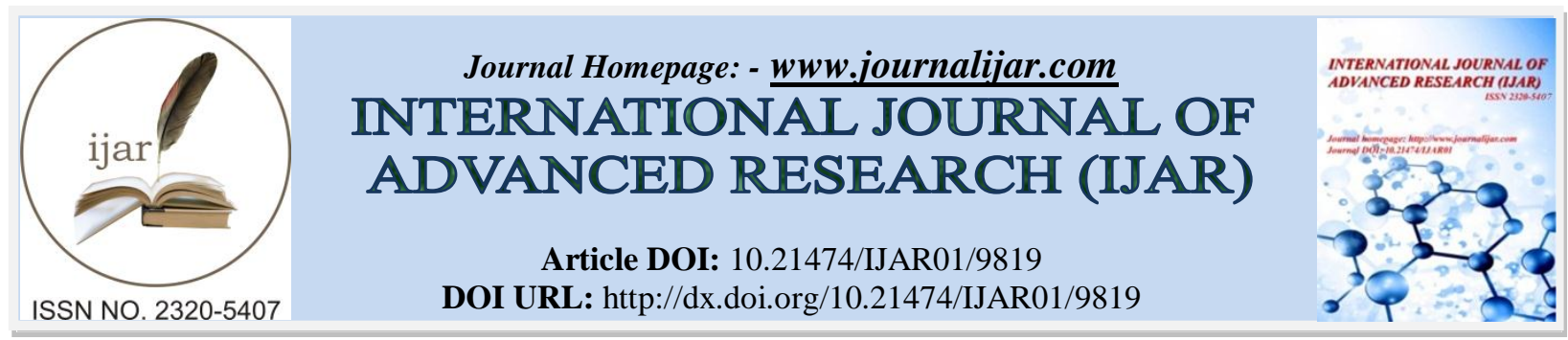

RESEARCH ARTICLE

\title{
TRAINEE TEACHERS' PERCEIVED ADVANTAGES, BARRIERS AND SUPPORTS OF COMPUTER TECHNOLOGY IN PRIMARY SCHOOLS IN RIFT VALLEY, KENYA.
}

\author{
Lilian C. Kimaiyo. \\ Department of Educational Psychology, Tom Mboya University College.
}

\section{Manuscript Info}

Manuscript History

Received: 04 August 2019

Final Accepted: 06 September 2019

Published: October 2019

Key words:-

Trainee Teachers' Perceived Barriers,

Supports Required, Introduction of

Computer Technology.

\begin{abstract}
The purpose of this study was to determine the Trainee Teachers' Perceived, Advantages, Barriers and Supports Required with the Introduction of Computer Technology in Primary Schools in Kenya. The study was done in Rift Valley, Kenya. The study employed qualitative research strategy. The researcher purposely selected five public TTCs in former Rift Valley Province for the study. Stratified simple random sampling was used to select a total of 100 participants. Qualitative data was collected using an interview guide during focus group interviews of pre-service teachers. Descriptive statistics was employed to analyze qualitative data. The descriptive statistics involved the use of frequencies, means and standard deviation. Qualitative data was further analyzed thematically using data reduction, conclusion drawing and verification techniques. Data was presented in form of texts and tables. The study established that teacher trainees support introduction of ICT in Kenyan primary schools because it has potential advantages. Majority of the respondents agreed that there were advantages associated with the introduction of ICT in primary schools in Kenya. In addition to benefits of ICT integration, trainee teachers cited some disadvantages of ICT use and suggested supports that would promote ICT integration.
\end{abstract}

Copy Right, IJAR, 2019,. All rights reserved.

\section{Introduction:-}

Information and Communication Technology (ICT) is one of the principal drivers of economic development and social change worldwide. Torero and Braun (2006) offered a broad definition of ICT which encompasses equipment and services. For them, ICT includes the computing industry (hardware, software, networks, the Internet, and related services); electronic data processing and display (such as photocopiers, cash registers, calculators, and scanners, as well as a myriad of less well-known machines specifically tailored to production and manufacturing. It also includes telecommunications and related services (such as fixed and cellular telephones, facsimile machines, instant messaging, teleconferencing among others.); and audiovisual equipment and services (including television, radio, video, DVDs, digital cameras, compact discs, MP3 players, etc). Information and Communication Technology plays a key role in enhancing the quality of education. However, successful implementation of ICT requires strategic planning (Ngoma, 2010). The role of electronic technology in promoting economic growth and development has gained prominence globally (Tinio, 2009). 


\section{Literature Review Teacher Perceptions}

The educational potential of computer technology has been emphasized by many researchers (Chigona,Wallace\& Zane, 2014; Hennessy et al, 2010). Hennesy et al (2010) stress the potential of computer technology to present rich learning environments, allowing learners to adopt multiple perspectives on complex phenomena, to foster flexible knowledge construction in complex learning domains, and to cater for individual differences. Further (Chigona et al, 2014) suggest that ICT facilitates the opportunity for more student-centered teaching, more self-learning and more peer teaching. It also provides greater opportunity for teacher to teacher and student to student communication. Since the introduction of educational technologies into classroom settings, teacher education has faced the challenge of improving in-service teacher education and preparing pre-service teachers for successful integration of computer educational technologies into their teaching and learning practices. In recent years, teacher education colleges have made efforts preparing pre-service teachers to integrate computer technology into their future teaching practices (Ertmer\&Ottenbrent- Leftwich, 2010; Angeli\&Valanides, 2009). In Kenya Primary Teacher Training Colleges, for example, ICT is a core compulsory subject in both years of study though not examinable (Kenya.MoEST, 2014 ; Center for International Education, 2010). Over the past seven years, there has been an ongoing pressure in Kenya led by Ministry of Education, with the intention to integrate computers and ICT in teaching and learning (Farrell, 2007). However, studies in Western Europe (Nivala, 2009; Teknikdelegatione, 2010) and in Kenya (Ndiku, 2003) indicate that there is little evidence that ICT has actually enhanced education standards. This is despite considerable effort and resources put into educational computing by governments worldwide. Rushby (2005) has described the situation in terms of waves where different technologies have promised to deliver a revolution in teaching and learning but after a period of time have resulted in disappointment and little substantial change. Studies reveal that despite availability of hardware (Sang,Valke,VanBraak\&Tondeur, 2010), school related support for ICT integration (Baylor \& Ritchie, 2002) and teacher consciousness about benefits of ICT use (Pelgrum, 2001), a small number of teachers have chosen to use ICT in education while majority have not (Teknikdelegationen, 2010). Reporting reasons for slow integration, Ertmer (1999) categorized barriers to ICT integration into two: first order (external) and second order barriers (internal). He considered external barriers as issues related to access to technologies, training and school support, whose absence makes technology integration impossible. Ertmer (1999) goes further to suggest that even if the first order barriers are resolved, not all teachers integrate ICT. It is therefore important to consider the second order (internal barriers) discouraging computer technology integration by teachers. This includes teacher philosophy about teaching and learning, teacher perceived competence about computer, and about teaching, perceived usefulness (computer attitudes) and subjective norms (opinions and suggestions of people who are important to them). This study aimed at examining perceived advantages, barriers and supports of computer technology integration in primary schools in Kenya.

Most research exploring the implications of integrating computers in the Classroom in western countries targets elementary and secondary schools (Rosen Weil, 1995; Ross, Hogabaum-Gray \&Hannay, 2001). No research in Kenya has examined their effect from the perspective of prospective teachers, that is, those who will be involved in the implementation of the laptop project.

Because teachers serve a pivotal role in determining just how much advantage can be gained from using computers, it is critical that we understand their perspective. This study will also examine issues facing student teachers as they consider integrating technology in their curriculum in line with government policy of one laptop per child. The introduction of computer technology for very young learners in western countries has met with both support (Shade \& Watson, 1990) and concern (Barnes \& Hill, 1983; Elkind, 1996). Initially, there were fears that using computers with preschoolers would result in poorer social skills, less active learning opportunities, and fewer age-appropriate play activities (Barnes \& Hill; Kaden, 1990; Zajonc,1994). More recent research suggests that computers can facilitate social, cognitive, and play development among very young learners when handled appropriately (Kelly \&Schorger, 2001; Ko, 2002; Sandberg, 2002). However, debates about the value and desirability of computers for young learners continue (Plowman\& Stephen, 2003). This researcher found it important to investigate the perceptions of the primary school student teachers who will experience the effects of computers directly.Research with elementary and secondary school educators points to a number of potential variables that can affect the integration of computers in the higher grades, and some of these variables may be important in class one education environments as well (Wood, Specht \& Willoughby, 2008). Both barriers and supports for integrating computer technology in the classroom have been identified. For example, barriers include equipment-related issues such as limited access, technical problems, and malfunctions (Hadley \&Sheingold, 1993; Rocheleau, 1995); skill-related concerns such as lack of educator training and limited knowledge (Becker \&Ravitz, 2001); and attitudinal issues 
such as educator anxiety and concerns about the change to the social structure in classrooms (Rosen \& Weil, 1995; Schofield, 1995). Supports include access to in-house specialists, technical support, administrative support, and opportunities for training (Tsitouridour\&Vryzas, 2003).

The relevance and the relative importance of each of these factors in early primary education in Kenya, will be established by this study through focus group interviews. In addition, the early primary education environment has features that make it distinct from higher-grade contexts (e.g., level of independence and basic skills in young children), and these unique elements may require supports and produce barriers that are not found in higher-grade environments. This study is expected to fill this gap.

\section{Computer use in Education}

Researchers have come up with a range of definitions, classifications and typologies about educational computer use. For instance, Educational computer use has been categorized as "computers as information resource tools", "computers as authoring tools" and "computers as knowledge construction tools" (Ainley, Banks, \& Fleming, 2002). On the base of an empirical study, involving a large number of teachers, Tondeur, Van Braak, and Valcke (2007) have delineated two main categories of ICT use by teachers: supportive ICT use and classroom ICT use; these categories replicate in an empirical way typologies developed by e.g., Hogarty, Lang, \&Kromrey (2003), and van Braaket al., (2004). The first category, supportive ICT use, refers to the use of ICT for pro-active and administrative teaching tasks, such as student administration, preparing worksheets, developing evaluation activities, keeping track of pupils' learning progress, etc. The second, classroom ICT use, aims to support and enhance the actual teaching and learning process, such as the use of computers for demonstration purposes, drill and practice activities, modeling, representation of complex knowledge elements, discussions, collaboration, project work, etc. (Hogartyet al., 2003). To study the relationship between both categories, it is interesting to build on the study of Wozney, Venkatesh and Abrami (2006). They found that supportive use of ICT was the most significant predictor of classroom use of ICT.

\section{Methodology:-}

This study was done in five public Teacher Training Colleges in former Rift Valley Province of Kenya. The research population for the study was all teacher trainees in pubic teacher training colleges in Rift Valley. The colleges had a total population of 5,075 student teachers. Out of the total population 2,458 were female while 2,617 were male. Student teachers were divided into two major categories: those in first year of study and those in the second year of study (Research data,2015). Stratified simple random sampling was used to select twenty student teachers from each of the five Teacher Training Colleges (TTCs), giving a total of 100 participants.

To establish student teachers perception on the introduction of computer in primary education this study used qualitative research strategy. Focus group discussion was applied as it is an effective method for gathering a wealth of information through an organized, open-ended, and flexible discussion (Marshall \&Rossman, 1989).

In order to gauge the perceptions of the student teachers on the introduction of computer technology in primary schools in Kenya accurately and comprehensively, the present study used focus group interview. Focus group interview refers to a group interview on a specific topic. It is an open-ended group discussion guided by the researcher (Robson, 2002). Its use is relatively inexpensive and flexible. Participants who may be reluctant to be interviewed on their own are likely to participate. An interview guide developed by the researcher was used during focus group in-depth interview. The interview guide was considered appropriate because of its potential to generate detailed and relevant responses to important questions of the study. Reliability of the interviews was enhanced by careful piloting of interview schedule, careful training of interviewers and use of closed questions as suggested by Silverman in Cohen et al (2007).

The responses to the interview schedule were recorded by audio tape recording and taking notes. Tape recording made it possible to re analyze the data in order to test the objectives, establish reliability, speed up data collection and limit interruptions in communication (Rubbin \& Rubbin, 2005). The researcher combined note taking during the interview and digital recording of the interview for permanent record and to capture non verbal cues.

In every institution, twenty sampled student teachers were requested to attend the focus group interview .Of these ten were first year's five males and five females. The second group consisted of second years, five males and five females. These twenty respondents were randomly selected from the participants of the survey. At the outset it was 
made clear that there is no right or wrong answers and that all the comments provided would be helpful toward increasing our understanding of the use of computers with young learners.

Specifically, the researcher used focus groups as an opportunity to determine how computers will be used in primary education environments, and how the use of computers might or might not fit within existing pedagogical beliefs or other constraints in primary school education environment. The student teachers were asked to explain what in their view would be the advantages and disadvantages of integrating computer technology in primary education. Further, student teachers were encouraged to explore barriers or reasons for opting not to use computer technology, when computers become available. After this brief introduction, the tape-recorder and video-camera were turned on, and the researcher and two assistants began the session by asking questions in the interview guide.

\section{Qualitative Analysis}

Data analysis in qualitative research is an interactive, ongoing process in which data collection and analysis influenced each other. As data was being collected, it was being analyzed. The evolving field text revealed emerging patterns or further questions that needed exploration (Denzin \& Lincoln, 2005). Data collection continued until existing themes accounted for all variation in the data and no new information was being collected as suggested by Miller, in Hanley-Maxwell, et al. (2007).

To ensure trustworthiness of the data, iterative questioning as proposed by Shenton (2004) was employed as a means of verifying information being provided by participants. Questions were rephrased and re-presented so that answers could be compared for consistency. Moreover, the researcher relied on actual words of participants when analyzing and coding the data in order to ensure that the meanings derived remained true to the voice of participants. As suggested by Taylor- Powell and Renner (2003), this allowed the themes and categories to emerge from the data rather than having the researcher impose preconceived notions on the data. Peer review, which provides an external check on the research process, was also used to ensure credibility and trustworthiness of the findings. These codes derived during analysis as well as the preliminary interpretations were critiqued by peers from the department of Educational Psychology (Onwuegbuzie \& Combs, 2010; Cresswell, 2007).

Qualitative analysis commenced on collected data through interview schedule with key respondents. The audiotaped data was transcribed and recorded in written form (Onwuegbuzie \& Combs, 2010). The data was edited and a more formalized analysis process subsequently commenced where the data was re-grouped according to research questions.Data was examined sentence by sentence while defining ideas that are explicit. This allowed the researcher to build ideas inductively while preventing imposition of existent theories and researchers own beliefs on the data (Chamaz, 2000). In this research the researcher used analysis techniques such as data reduction, data display, and conclusion drawing and verification. Data reduction was the process of identifying relevant data to the study. These were then organized and the various themes were identified and coded as suggested by Marshall and Rosman, (1999) . Conclusion drawing involved considering the larger meanings and implications of the data as they relate to the purpose of the study. Excerpts of verbatim texts from the data were lifted and placed according to their specific themes while using pseudo names for purposes of confidentiality. Another data analysis technique that was employed was memo writing which was carried out throughout the process. In the memo, the researcher wrote down thoughts, interpretations and hypotheses about observations in the field and emerging categories, themes and theories. According to Saunders et al (2003) this helped in later stages of qualitative analysis.

The thematic analysis was used where the responses were arranged according to the various themes as per the research questions. As observed by Gray (2004) qualitative data provides rich descriptions and explanations that demonstrate the chronological flow of events as well as often leading to chance findings. 


\section{Results:- \\ Descriptive statistics of teacher trainee perceptions on ICT integration}

From the findings in table 4.25 , most of the respondents $(n=231,74.3 \%)$ agreed that trainee teachers supported introduction of computer technology in primary schools, $(n=53,17 \%)$ disagreed, while $(n=27,8.7 \%)$ were undecided as shown with a mean score of 3.84. On whether the college offered theoretical and pedagogical model training, most $(n=198,63.7 \%)$ of the respondents agreed, $(n=78,25 \%)$ disagreed while $(n=35,11.3 \%)$ were undecided as supported by a mean score of 3.49. On whether the introduction of computer technology will fit theoretical framework, approaches or orientation of their training most trainee teachers $(n=229,70.2 \%)$ agreed that it fitted, $(n=50,16.1 \%)$ disagreed, while $(n=42,13.5 \%)$ were undecided as shown by a mean score of 3.75 .

From the study most of the respondents $(\mathrm{n}=273,87.8 \%)$ agreed that there were potential advantages of computer use, $(n=22,7.1 \%)$ disagreed, while $(n=16,9.9 \%)$ were undecided as summarized with a mean score of 4.22 . On whether trainee teachers obtain the supports required for effective use of computer, majority $(n=232,71.4 \%)$ agreed, $(\mathrm{n}=54,17.4 \%)$ disagreed, while $(\mathrm{n}=35,11.3 \%)$ were undecided as supported by a mean score of 3.73 . Finally, at least $(n=173,55.7 \%)$ of the respondents disagreed that they had fears about introduction of computer technology in primary school, $(n=116,34.1 \%)$ agreed, while $(n=32,10.3 \%)$ were undecided as shown by a mean score of 2.64.

From the descriptive statistics of the study, it is clear that most trainee teachers supported introduction of computer technology in primary schools, TTCS offered theoretical and pedagogical model training favorable to computers and the introduction of computer technology fit theoretical framework, approaches and orientation of their training. Most of the respondents agreed that there were potential advantages of computer use and that trainee teachers obtained the supports required for effective use of computer. Results further indicate that most of the trainee teachers had no fears about introduction of computer technology in primary schools in Kenya.

Table 4. 1:-Descriptive statistics of Student teachers perceptions on the introduction of computer technology

\begin{tabular}{|c|c|c|c|c|c|c|c|c|c|c|c|c|}
\hline \multirow[t]{2}{*}{ Statement } & \multicolumn{2}{|c|}{\begin{tabular}{|l}
$\begin{array}{l}\text { Strongly } \\
\text { agree }\end{array}$ \\
\end{tabular}} & \multicolumn{2}{|c|}{ Agree } & \multicolumn{2}{|c|}{ Undecided } & \multicolumn{2}{|c|}{ Disagree } & \multicolumn{2}{|c|}{$\begin{array}{l}\text { Strongly } \\
\text { Disagree }\end{array}$} & \multirow[t]{2}{*}{ Mean } & \multirow[t]{2}{*}{$\begin{array}{l}\text { Std } \\
\text { dev }\end{array}$} \\
\hline & Freq & $\%$ & Freq & $\%$ & Freq & $\%$ & Freq & $\%$ & Freq & $\%$ & & \\
\hline $\begin{array}{l}\text { Student teachers support introduction } \\
\text { of computer technology in primary } \\
\text { schools }\end{array}$ & 115 & 37.0 & 116 & 37.3 & 27 & 8.7 & 20 & 6.4 & 33 & 10.6 & 3.84 & 1.28 \\
\hline $\begin{array}{l}\text { Our college offer theoretical and } \\
\text { pedagogical model training }\end{array}$ & 65 & 20.9 & 133 & 42.8 & 35 & 11.3 & 44 & 14.1 & 34 & 10.9 & 3.49 & 1.27 \\
\hline $\begin{array}{l}\text { An introduction of computer } \\
\text { technology fit theoretical framework, } \\
\text { approaches or orientation of my } \\
\text { training }\end{array}$ & 87 & 28.0 & 132 & 42.4 & 42 & 13.5 & 27 & 8.7 & 23 & 7.4 & 3.75 & 1.17 \\
\hline $\begin{array}{l}\text { There are potential advantages of } \\
\text { computer use }\end{array}$ & 142 & 45.7 & 131 & 42.1 & 16 & 5.1 & 9 & 2.9 & 13 & 4.2 & 4.22 & 0.98 \\
\hline $\begin{array}{l}\text { I obtain the supports required by } \\
\text { teachers for effective use of } \\
\text { computer }\end{array}$ & 92 & 29.6 & 130 & 41.8 & 35 & 11.3 & 22 & 7.1 & 32 & 10.3 & 3.73 & 1.25 \\
\hline $\begin{array}{l}\text { I have fears about introduction of } \\
\text { computer technology in primary } \\
\text { school }\end{array}$ & 56 & 18.0 & 50 & 16.1 & 32 & 10.3 & 72 & 23.2 & 101 & 32.5 & 2.64 & 1.51 \\
\hline
\end{tabular}

4.2 Student teachers perceived advantages and disadvantages of ICT use in primary schools in Kenya

The objective was to asses student teachers perceived advantages and disadvantages of ICT use in primary schools in Kenya. Realizing the effects of ICT on the workplace and everyday life, the Kenyan Government has introduced one laptop per child project in order to bridge the existing technology gap, promote meaningful learning and enhance skills that will in future promote professional productivity (Tomei, 2005). Understanding trainee teacher's perceptions on advantages and disadvantages of the laptop project was key to successful adoption as suggested by Watson (2006). 


\section{Advantages of ICT use}

Majority of the respondents agreed that there were advantages associated with the introduction of ICT in primary schools in Kenya. Most trainee teachers interviewed indicated they will be able to access a wider range of resources online which promote accuracy of information being taught to learners.

There is lots of information in the internet ... I think I will google to verify information before I go to class to teach, besides more current information is available online"

Trainee teachers were of the opinion that integration of ICT will ensure that learners will acquire computer skills. Pupils will be able to learn how to use computers, use internet to find information, ... use e-mail and social media and create documents with a word processing program

Most trainee teachers agreed that the acquisition of ICT skills not only improve the learning process but will prepare young learners for the labor market, careers and future lives.

Trainee teachers opined that ICT would make learning easy. More subject content would be delivered quickly. One said

...I think ICT use will get across content easily and quickly. More of the syllabus will be covered.

Trainee teachers viewed ICT as an excellent tool for managing information on pupils work and analysis of their work.

... I will be able to keep records of pupils' performance analyze and draw graphs. That way it will be easy to track how they are performing

Trainee teachers agreed that ICT use is likely to create interest to learn subject content. This interest will translate into increased participation and better positive behavior in the classroom.

... I think the pupils will want to learn, they ...want to participate, they will pay more attention than when I am talking and writing on the board, they will be more interested in what is being taught.

Most trainee teachers were of the opinion that ICT integration will promote greater flexibility in teaching. Teachers and learners will be able to communicate beyond class time over the internet. They hoped to communicate with learners through social network sites such as Whats up and Face book to keep classroom discussions going as well as give assignments.

...the learners are digital. They will be interested to use face book and Whats up to post their contributions to a topic... and I will just post a topic to be discussed and await their comments which I will then compile...that way learning will go on outside class...

Moreover trainee teachers foresaw the possibility of using e-mail facilities to give assignments to learners and receiving feedback on assignments from learners.

...It will be possible to give and receive assignments and also be able to give feedback to learners trough e-mail. Trainee teachers foresaw learning shifting from teacher - centered to learner- centered approach.

... the teacher will introduce a topic ...put learners in groups and allow them to search information from the internet... then just visit each group in turns to find out what is going on,... direct them,.. then visit the next group ...that way the teacher will do less and talk less... That will lessen teachers' work.

Student teachers expressed the view that through better data analysis, classes can be tailored to learners' strengths and weakness. Teachers can use ICT to vary their approach in order to cater for the different types of learners in class.

...learners who easily get bored with just books, talking and chalk board will be visually stimulated...the weak will get individual attention ...this is not possible if I am just dictating notes...

\section{Disadvantages of ICT use}

In addition to benefits of ICT integration, trainee teachers cited some disadvantages of ICT use .The most commonly cited disadvantage was the high cost of acquisition of hardware and soft ware. 
...ICT integration is valuable but the cost of acquisition of hard ware and software is prohibitive ...the government may spend a lot of money which could otherwise be useful for other projects...

In addition learners are likely to stray away from educational purposes of ICT. Learners may use the machines to visit social sites which can lead to harmful exposure.

... ICT can be a source of distraction to young learners... they can get excited with technology and lose sight of the purpose of learning ... it can be entertainment rather than education ... some sites may be harmful to them Some trainee teachers noted with concern that ICT use may cause eye problems and may affect pupil -teacher relationship. In fact it was reported by one

...computer may cause eye problems to both learners and teachers ... there might be situations when learners get used to learning through ICT ... so when you have a different type of lesson where ICT is not involved ...they will not listen to you... they may even disrupt the class...

One said,

... pressure to complete syllabus on time may hinder ICT use... setting up ICT classroom and clearing after, before the other teacher gets in ... it may take up valuable lesson time...

Frequent ICT use may promote individualism among pupils. Learners may get too engaged with computers and in the process forget to interact with their peers.

... i think pupils' interaction with one another will be affected...they may not play with friends... they may prefer computer games.

The implication of this is that teacher trainees are well aware of challenges associated with ICT integration in primary schools and they will be able to handle them as they come.

\section{Barriers to the implementation of ICT integration in primary schools}

Barriers are challenges which have to be overcome in order to attain a goal (Bromme, Hesse and Spada (2005). Working with ICTs in primary schools is new and teachers and learners have to establish new ways of doing things. Ertmer (1999) classified barriers to ICT integration into two categories; extrinsic and intrinsic. Balankat, Blamire\&Katal (2007) outlined teacher level barriers as lack of teacher ICT skills, lack of teacher confidence, lack of pedagogical teacher training programs.

Teacher trainees in this study cited lack of electricity in most primary schools in Kenya as a likely barrier

....there is no electricity in most primary schools .... in remote areas.. How will teachers use ICT in such areas?

Trainee teachers also noted the Possibility of theft of computers from school labs and stores and likelihood of damage while on transit. This may lead to huge losses being incurred by schools. One of the trainee teachers, Paul said the following concerning challenges:

...laptops issued to class one pupils are likely to be damaged while on transit between home and school... It may fall down or be rained on ... If they are stored in school, they may be stolen from the store, like happens to textbooks.

The view that lack of ICT skills among teachers and therefore were not adequately prepared was expressed by teacher trainees.

Jane said:

...Some of us may not be ready to teach using laptops because we feel inadequately trained... you see all computers are in the laboratory yet every time there is a lesson in the computer laboratory or it is locked ... there is little time to practice applying skills taught

Lack of time was another issue identified by trainee teachers as a likely barrier. Most respondents felt that thirty five minute lesson time was inadequate for ICT use.

Ben said,

...It is difficult to set up and use ICT in the 35 minutes allocated for one 
lesson $\quad$... especially with pressure to complete the syllabus.

Other likely barriers to ICT use expressed by student teachers were negative teachers attitude, unreliability of power sources, high cost of repair and maintenance, limited access to ICT hardware by teachers and pupils, lack of appropriate administrative support and crowded classrooms.

Grace said,

well...there will be problems you know......especially if the school administration does not purchase replacement of hardware or does not repair broken down computers on time...at times the classes may be too overcrowded to allow all students to access the few computers available.

It is the view the researcher that teacher trainees perceived real barriers to ICT integration that needed to be addressed before the program is rolled out.

\section{Likely supports to ICT integration in primary schools}

Focused group interview results concerning possible supports yielded the following suggestions from trainee teachers; improving access to computer by allocating more money, offering more ICT related courses to teacher lesson teaching such as Mathematics, Social studies, Science etc, during teaching practice. Other trainee teachers suggested in- service training for teachers, provision of technicians in every school to repair and maintain hardware, personal computers be provided for teachers to be used for lesson preparation. Other trainee teachers suggested more computer laboratories be made available in TTCs to improve access and practice.

One of the trainee teachers, Dan said

......May be all trainee teachers should sit for ICT proficiency exam at the end of their $\quad$ training.

Extent and nature of trainee teacher ICT use in T.T. Cs

This section looks at the nature of ICT facilities. These findings were based on focus group interview of trainee teachers in sampled T.T. Cs in the North Rift. These findings were triangulated with findings from observation by the researcher Data from these colleges indicated that ICT facilities are inadequate as shown in table 1.

Table 1:-Extent and nature of student Teachers ICT use

\begin{tabular}{|l|l|l|l|l|}
\hline College & Number of computer labs & $\begin{array}{l}\text { Total number of No. of computer } \\
\text { computers in lab }\end{array}$ & $\begin{array}{l}\text { Connection } \\
\text { technicians }\end{array}$ \\
\hline A & 3 & 120 & 1 & Someternet \\
\hline B & 2 & 150 & 1 & Sometimes \\
\hline C & 2 & 135 & 1 & Sometimes \\
\hline D & 2 & 100 & 1 & Sometimes \\
\hline E & 2 & 90 & 1 & Sometimes \\
\hline
\end{tabular}

From table 1 the five TTCs had an average of 118 computers and two computer laboratories. All colleges had a qualified computer technician. This shows that T.T.Cs were moderately equipped with ICT hardware when compared with student teacher population. Trainee teachers in the T.T.Cs reported lacking appropriate software for course content. Moreover tutors in the TTCs rarely integrated ICT in their classroom so as to serve as models to trainee teachers.

One trainee teacher, Otieno said:

Most tutors do not use ICT in their classrooms due to lack of interest and skills. ... It is only the ICT teacher who may present his lesson in power point form.

The ICT tutor is the one charged with teaching the teacher trainees basic Microsoft officepackages and basic computer skills. This is a compulsory course though not examinable.Further observation by the researcher indicated that it is only the ICT lessons done in computer laboratories that integrate ICT. Teachers expressed the fact that every time the computer lesson is completed the laboratory is locked therefore there is little time for practice. This is one factor that could have contributed to negative trainee teacher computer competence and attitude. Teacher trainees need to apply ICT skills during their training in order to be able to apply it in their future teaching. Levin \&Wadmay (2008), suggested that, teacher trainees, when given time to practice with technology, learn, share and collaborate with peers, it is likely that they will integrate ICT into their teaching. 


\section{Common uses of I.C.T}

From the data collected, most trainee teachers reported that the common uses of computers in TTCs by them was for learning ICT lessons. These further proofs that trainee teachers have limited use of ICT while undergoing training and this may inhibit their integration into future teaching.

\section{Fears related to introduction of computer technology in primary schools}

Findings of this study indicate that all teacher trainees in the focus groups indicated that they supported the government one laptop per child project. Most of them however expressed their fears about the success of the project and the effects of implementing ICT learning in all public primary schools. Some of their fears were: it is a giant project that is not priority when the schools are faced with many other needs... Pupils may get exposed to sites on the internet that are not relevant to learning... Computers may be stolen from pupils on their way home or from school stores... Not all teachers have skills to teach using computer.There is need for intense training for both in service and trainee teachers.It is clear that trainee teachers interviewed feared the high cost of soft ware and hardware, teacher's lack of skills to update course content and teach with computer, fear for safety of computers and fear of exposure to sites not relevant to learning. Others feared that the computer may affect the relationship between the teacher and their pupils. Pupil to pupil interaction may also be limited leading to development of individualism. This agrees with views of Barners and Hill (1990) and Zajonc (1993) who feared that using computers with pre-schoolers would result in poorer socialization and fewer age appropriate play activities. These findings are key to understanding perceptions of teacher trainees about ICT in primary schools, as this is key to successful adoption (Watson, 2006). It is recommended by this researcher that the MOEST should move fast to allay these fears before rolling out the project.

\section{The Extent and nature of student teacher ICT use in T.T.Cs}

Findings indicated that the five TTCs have an average of 118 computers and two computer laboratories. All colleges have a qualified computer technician. This shows that TTCs are moderately equipped with ICT hardware when compared with student teacher population. Trainee teachers in the TTCs reported lacking appropriate software for course content. Moreover, tutors in the TTCs rarely integrated ICT in their classroom so as to serve as models to trainee teachers. Further observation by the researcher indicated that it is only the ICT lessons done in computer laboratories that integrate ICT. Teachers expressed the fact that every time the computer lesson is completed the laboratory is locked therefore there is little time for practice. This is one factor that could have contributed to negative trainee teacher computer competence. Teacher trainees need to apply ICT skills during their training in order to be able to apply it in their future teaching. Levin \&Wadmay (2008) suggested that, teacher trainees, when given time to practice with technology, learn, share and collaborate with peers, it is likely that they will integrate ICT into their teaching.

\section{Conclusion and recommendations:-}

The study established that teacher trainees support introduction of ICT in Kenyan primary schools because it has potential advantages. Perceived advantages include promotion of computer literacy for both teachers and pupils, access to wider range and accurate information, teaching and learning is made easy, promote flexibility in teaching and learning among others. In view of this finding, the researcher can predict great success in ICT integration in primary schools in Kenya. This is because understanding teacher trainees' perceptions of computer which is an innovation, is key to successful adoption as suggested by Watson (2006).

The study established that teacher trainees foresee real challenges that may affect implementation of ICT integration. They include lack of electricity in some schools, concern over security of computers, high cost of repair and maintenances, restrictive curriculum and limited teacher ICT skills. It is the view of this researcher that some of these challenges need to be tackled before the project is fully rolled out.

The study sought to find out the extent and nature of trainee teacher ICT use in TTCs. This study established that TTCs have inadequate ICT hardware and soft ware for students use. On average TTCs had two computer labs that were locked most of the time unless there was an ICT lesson going on. This limited trainee teachers' access to ICT resources for practice. In view of this finding, the researcher has fears that trainee teachers may not be adequately skilled to implement ICT integration in primary schools in Kenya.

The study recommends that to overcome some of the disadvantages of ICT integration, teacher trainees and inservice teachers should, Choose content and control pupil usage of ICT. Learners' time using ICT should be 
regulated to reduce possibilities of exposure to harmful sites, explain concept of ICT to the child so as to promote responsible use while on their own now and in the future, ensure there is balance between child's activities where there is equal distribution between child's play indoors and between individual play and group play. .In view of the fact that security of ICT hardware and software was a major concern of the respondents, this research recommends that schools construct secure stores to ensure safety of the computers once the programme is rolled out.

This study found out that teacher level barriers include lack of teacher ICT skills, lack of teacher confidence, lack of pedagogical teacher training programs.Teacher trainees in this study cited the following as likely barriers to ICT integration in Kenyan primary schools.Lack of electricity in most primary schools. Possibility of theft of computers from school labs and storesUnreliability of power sources, High cost of repair and maintenance, High cost of purchasing software and hardware, Likelihood of damage while on transit, Limited access to ICT hardware by teachers and pupils, Inadequate time for lesson preparation and presentation, Lack of appropriate administrative support, Crowded classrooms, Other likely barriers to ICT use expressed by student teachers were negative teachers' attitude, lack of teacher skills which may make it uncomfortable for them to use for instruction.Likely supports to ICT Integration in primary schools includeImproving access to computer by allocating more money, Offering more ICT related courses to teacher lesson teaching such as Maths, social studies, science etc, during teaching practice, In services- training for teachersProvision of technicians in every school to repair and maintain hardware, Personal computers be provided for teachers to be used for lesson preparation, More computer laboratories be made available in TTCs to improve access and practice, ICT proficiency exam for trainee teachers at the end of their training.

\section{References:-}

1. Angeli, C., \&Valanides, N. (2009). Epistemological and methodological issues for the conceptualization, development, and assessment of ICT-TPCK: Advances in technology and pedagogical content knowledge (TPCK). Computers and Education, 52, 154-168.

2. Barnes, B., \& Hill, S. (1983, May). Should young children work with microcomputers— Logo before Lego? Th e Computing Teacher, 11-14.

3. Barnes, B.J., \& Hill, S. (1990). Should young children work with microcomputers-Logo before Lego? The Computing Teacher, 10(9), 11-14.

4. Center for International Education (2010).Teacher preparation and continuing professional Development in Africa (Kenya)

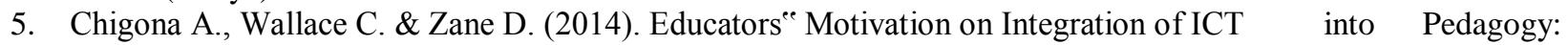
Case of Disadvantaged Areas. South African Journal of Education, 34(3), page 859.

6. Creswell, J. W. (2007). Qualitative inquiry and research design: Choosing among five approaches (2nd ed.). Thousand Oaks, CA: Sage.

7. Ertmer, P. A. (1999). Addressing first- and second-order barriers to change: Strategies for technology integration. Educational Technology Research and Development, 47, 47-61.

8. Hadley, M., \&Sheingold, K. (1993). Commonalities and distinctive patterns in teachers' integration of computers. American Journal of Education, 101, 261-315.

9. Kelly, K., \&Schorger, J. (2001). "Let's play puters": Expressive language use at the computer centre. Information Technology in Childhood Education Annual, 12, 125-138.

10. Levin, T., \&Wadmany, R. (2008). Teachers' views on factors affecting effective integration of information technology in classroom: Developmental Scenery. Journal of Technology and teacher Education, Vol.16,2,pp.233-236

11. McIntosh, D.N., Druckman, D., \&Zajonc, R.B. (1994). Socially induced affect. In Druckman, D., \& Bjork, R.A. (Eds.), Learning, remembering, believing: Enhancing human performance (pp. 251-276 and 364-371). Washington, DC: National Academy Press.

12. Ndiku, L. (2003). The Problems Encountered by School Personnel in the Implementation of Computer Use in Secondary Schools in Uasin Gishu District, Unpublished Thesis: Moi University Eldoret.

13. Ngoma, S. (2010). ICT in Education: A catalyst for Economic Growth in the Congo Retrieved March 19, 2015 from http://www.ictinedtoolkit.org/icttool/usere/pdfs/ICTs_for_Education_Resources.pdf

14. Nivala, M. (2009). Simple answers for complex problems: Education and ICT in Finnish information society strategies. Media, Culture \& Society, 31, 433-448.

15. Pelgrum, W. J. (2001). Obstacles to the integration of ICT in education: Results from a worldwide educational assessment. Computers and Education, 37, 163-178

16. Plowman, L. \& Stephen, C. (2003). A "benign addition"? Research on ICT and pre-school children. Journal of Computer Assisted Learning 19, 149-164. 
17. Rocheleau, B. (1995). Computer use by school-age children: Trends, patterns, and predictors. Journal of Educational Computing Research, 12, 1-17.

18. Ross, J. A., Hogaboam-Gray, A., \&Hannay, L. (2001). Effects of teacher efficacy on computer skills and computer cognitions of Canadian students in grades K-3. The Elementary School Journal, 102(2), 141 - 156.

19. Rushby, N. (2005). Editorial. British Journal of Educational Technology, 36, 135-136.

20. Sadaf, A., Newby, T. \&Ertmer, P.(2012). Exploring Factors that Predict Preservice Teachers' Intentions to Use Web 2.0 Technologies Using Decomposed Theory of Planned Behavior. Journal of Research on Technology in Education Behavior, 45, 171-195

21. Sandberg, A. (2002). Preschool teachers' conceptions of computers and play. Information Technology in Childhood Education Annual, 14, 245-262.

22. Sang, G. Y., Valcke, M., van Braak, J., \&Tondeur, J. (2010). Investigating teachers educational beliefs in Chinese primary schools: Socio-economical and geographical perspectives. Asia-pacific Journal of Teacher Education.

23. Shade \& Watson. (1990). Computers in early education: Issues put to rest, theoretical links to sound practice, and the potential contribution of microworlds. Journal of Educational Computing Research 6(4): 375-392.

24. Tashakkori, A., \& Teddlie, C. (Eds.). (2003). Handbook of mixed methods in social and behavioral research. Thousand Oaks, CA: Sage.

25. Teknikdelegationen, (2010). Framtidenslärande, idagensskola [Elektroniskresurs]: internationellforskningsöversiktkring IKT ochskola[The future of learning in today's schools [electronic resource]. Retrieved from http://www.teknik delegationen.se/bazment/teknikdelegationen/download.aspx?id=Rapport20101

26. Tinio,V.T.(2009). I C T in Education. United Nations Development Programme. Bureau for Development Policy, New York. N.Y

27. Tondeur, J., Devos, G., Houtte, M. V., Braak, J., \& Valcke, M. (2009). Understanding structural and cultural school characteristics in relation to educational change: the case of ICT integration. Educational Studies, 35(2), pp. 223-235.

28. Tondeur, J., van Braak, J., \& Valcke, M. (2008). Towards a typology of computer use in primary education. Journal of Computer Assisted Learning, 23, 197-206.

29. Torero,M\& Braun J.V(Eds)(2006). Information and Communication Technology for development and Poverty reduction : The potential of Telecommunications. Baltimore. The John Hopkins University Press

30. Tsitouridour, M., \&Vryzas, K. (2003). Early childhood teachers' attitudes towards computer and information technology: The case of Greece. Information Technology in Childhood Education Annual, 15, 187-207.

31. Van Braak, J., Tondeur, J., \&Valcke, M. (2004). Explaining different types of computer use among primary school teachers. European Journal of Educational Psychology, 19, 407-422.

32. Watson, G. (2006 ). Technology Professional development: Longterm effects on teacher self efficacy, Journal Of Technology and Teacher Education, vol.14,no 14,no.1,pp.151-166. 